\title{
Malignancy in Renal Transplant Recipients
}

\author{
(1) Ergün Parmaksız, • Meral Meşe, @ Serkan Feyyaz Yalın, \\ (1) Ali Burak Haras, 이 Okan Akyüz, (1) Zerrin Bicik Bahçabaşı
}

Department of Nephrology University of Health Sciences Kartal Dr. Lütfi Kırdar Training and Research Hospital, İstanbul, Turkey

Submitted: 13.08.2018 Accepted: 27.08 .2018

Correspondence: Ergün Parmaksız, SBÜ Kartal Dr. Lütfi Kırdar

Eğitim ve Araştırma Hastanesi, Nefroloji Kliniği, İstanbul, Turkey E-mail: drergnprmksz@hotmail.com

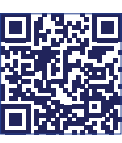

Keywords: Malignancy; renal transplantation; tumor type.

\section{ABSTRACT}

Objective: The types of post-transplantation malignancies may vary among different geographic regions and ethnic populations. The aim of the present study was to determine the risk and incidence of de novo carcinomas, clinical characteristics, and outcomes in renal transplant recipients (RTRs) who are followed up in our center and if there is an accumulation of one type of malignity and to examine screening procedures and frequency.

Methods: The files of 322 RTRs who were transplanted between January I, 2005 and December 3I, 2016 were screened retrospectively. The main data included the date of transplantation, patients' age, gender, date of the last follow-up, and cancer diagnosis.

Results: In eight patients $(M / F=7 / 1)$, de novo malignancy was identified. The mean age of patients with malignancy was $54.87 \pm 12.5$ years. The median duration of dialysis was 44 (2107) months. The average time from transplantation to tumor development was 50 (7-93) months. Malignity development rate was found to be $2.5 \%$ among all RTRs.

Conclusion: Every patient with renal transplantation should be followed up carefully by regular physical examination, laboratory findings, and imaging studies due to the risk of malignancy. Early diagnosis of malignancy is very important for both patient survival and functional renal graft. Renal transplantation is the most favorable renal replacement therapy, and complications, such as malignancy, that may develop later should be a cause to follow-up this treatment more carefully during the course of the procedure.

\section{INTRODUCTION}

Renal transplantation is considered as the best treatment choice of end-stage renal disease. However, renal transplantation has its own long-term complications. Renal transplant recipients (RTRs) are thought to have a higher risk of malignancy than the general population. ${ }^{[1-3]}$ Post-transplantation malignancies remain one of the major causes of mortality among RTRs and are anticipated to be the leading cause of death within the next 20 years. ${ }^{[4]}$ This risk is mainly attributed to the use of immune suppressive therapies during both induction and maintenance phases. The types of post-transplantation malignancies may vary among different geographic regions and ethnic populations..$^{[5]}$

The aim of the present study was to determine the risk and incidence of de novo carcinomas, clinical characteristics, and outcomes in RTRs who are followed up in our center.

\section{MATERIAL AND METHODS}

The files of 322 RTRs who were transplanted between January I, 2005 and December 3I, 2016 at the Nephrology Clinic were screened retrospectively.

After patients with graft removal $(n=4)$ and who died $(n=9)$ in this period were excluded, we analyzed $3 / 3$ patients' data.

The immunosuppressive protocol consisted of induction therapy and standard maintenance immunosuppressive triple therapy.

Induction therapy consisted of basiliximab (chimeric monoclonal antibody against interleukin 2), anti-thymocyte globulin (ATG), and methylprednisolone based on individual immunologic risk. Maintenance treatment comprised calcineurin inhibitors (CNls; cyclosporine A or tacrolimus) or inhibitors of mammalian target of sirolimus (sirolimus or everolimus), mycophenolate mofetil, and prednisolone.

A thorough pretransplant screening was conducted for occult malignancy, including chest $\mathrm{X}$-ray, thoracic computed tomography if needed, breast and abdominal sonography, urinalysis, fecal occult blood testing, screening for nasopharyngeal carcinoma, Pap smear, serum alpha-fetoprotein (AFP), and prostate-specific antigen (PSA) level.

All patients with chronic hepatitis $B$ or $C$ received antiviral therapy and achieved sustained acceptable viral response before renal transplantation.

In the follow-up period, observation of microscopic or gross hematuria is verified with cystoscopy. 
Table I. Clinical characteristics in eight cases of malignancies after renal transplantation

\begin{tabular}{|c|c|c|c|c|c|c|}
\hline Case & Age & Gender & Form of dialysis & $\begin{array}{c}\text { Duration of } \\
\text { dialysis } \\
\text { (month) }\end{array}$ & Primary disease & $\begin{array}{l}\text { Immunosuppressive treatment } \\
\text { (maintenance) }+ \text { induction }\end{array}$ \\
\hline I & 64 & Male & Hemodialysis & 2 & Unknown & (Tacrolimus+MMF+prednisolone), +ATG \\
\hline 2 & 58 & Female & Hemodialysis & 20 & Unknown & (Tacrolimus+MMF+prednisolone), +ATG \\
\hline 3 & 54 & Male & Peritoneal dialysis & 58 & Amyloidosis & (Tacrolimus+MMF+prednisolone), +ATG \\
\hline 4 & 31 & Male & Hemodialysis & 72 & Unknown & (Tacrolimus+MMF+prednisolone), +ATG \\
\hline 5 & 57 & Male & Hemodialysis & 30 & Unknown & (Tacrolimus+MMF+prednisolone), +ATG \\
\hline 6 & 45 & Male & Hemodialysis & 20 & Unknown & (Tacrolimus+MMF+prednisolone), +ATG \\
\hline 7 & 73 & Male & Hemodialysis & 58 & Polycystic kidney disease & (Sirolimus+MMF+prednisolone), +ATG \\
\hline 8 & 57 & Male & Hemodialysis & 107 & Polycystic kidney disease & (Sirolimus+MMF+prednisolone), +ATG \\
\hline
\end{tabular}

In addition, annual breast sonography and gynecologic examination for female RTRs and testing for serum PSA level for male RTRs are arranged. Patients with pretransplant native kidney cysts were checked by annual ultrasonography after renal transplantation.

For patients with hepatitis B or C virus infection, AFP and liver sonography are checked every 3 months. ${ }^{[6]}$

Patients with malignancy developed no immunosuppressive treatment prior to renal transplantation.

\section{Data collection}

The main collected data included the date of transplantation, patients' age, gender, date of the last follow-up, cancer diagnosis, how many years after renal transplantation cancer develops, and the induction and management therapies they received were recorded.

Additional data for risk factor evaluation were also collected as follows: reason for transplantation, duration and type of dialysis, donor type (deceased or living), induction and maintenance immunotherapy regimen at discharge, and allograft lifetime.

\section{Statistical analysis}

Descriptive statistics were performed for all data. Results were presented as mean $\pm S D$ for normally distributed data and as median (min-max) for dispersed data.

\section{RESULTS}

De novo malignancy was identified in eight patients (M/ $\mathrm{F}=7 / \mathrm{I})$. The mean age of patients with malignancy was $54.87 \pm 12.5$ years, and the median duration of dialysis was 44 (2-107) months. The average time from transplantation to tumor development was 50 (7-93) months.

Malignity development rate was found to be $2.5 \%$ among all RTRs. Five patients with malignancy were transplanted from living related donors, and three were from cadaveric source.

We determined that all of the patients with malignity received ATG as induction therapy, six patients were treated with tacrolimus, mycophenolate mofetil, and prednisolone as maintenance treatment, and in two patients, sirolimus was preferred instead of $\mathrm{CNI}$ because the primary renal failure etiology was polycystic renal disease (Table I).

Two patients had skin carcinoma, whereas renal cell carcinoma (RCC), hepatocellular carcinoma, thyroid papillary carcinoma, vulvar carcinoma, prostate carcinoma, and gastrointestinal stromal tumor were found in each other.

As soon as malignancy was diagnosed, immunosuppressive treatments were reduced, and patients were followed up closely for possibility of rejection.

Patients with skin carcinoma were excised locally, and surgical cure was provided. Patients were followed up closely.

The patient with thyroid papillary carcinoma underwent subtotal thyroidectomy and received radioactive iodine treatment, and no recurrence was observed.

The patient who had diagnosed native kidney with RCC underwent left nephrectomy. Further imaging studies were conducted to detect distant metastasis and followed up with no distant metastasis and recurrence.

The patient with gastrointestinal stromal tumor was started on imatinib mesylate treatment by the oncology

Table 2. Tumor type and time from transplantation (month) of renal transplantation recipients with malignancy

\begin{tabular}{lcc}
\hline Case & Tumor type & $\begin{array}{c}\text { Time from } \\
\text { transplantation } \\
\text { (month) }\end{array}$ \\
\hline 1 & Basosquamous skin cancer & 46 \\
2 & Vulvar carcinoma & 54 \\
3 & Thyroid papillary carcinoma & 69 \\
4 & Renal cell carcinoma & 7 \\
5 & Gastrointestinal stromal tumor & 80 \\
6 & Squamous cell carcinoma(lip) & 11 \\
7 & Prostate adeno carcinoma & 93 \\
8 & Hepatocellular carcinoma & 40 \\
\hline
\end{tabular}


department, and no recurrence was observed until today.

The patient with vulvar carcinoma was operated, surgical cure was provided, and distant metastasis was not detected.

The patient with hepatocellular carcinoma developed from hepatitis B had lamivudine prophylaxis. Tumor excision was performed, and there was no distant metastasis.

The patient with prostate adenocarcinoma did not accept operation or radiotherapy and was given only chemotherapy. He is currently followed up by the oncology department (Table 2).

\section{DISCUSSION}

The risk of developing cancer after renal transplantation is one of the important factors affecting long-term survival in transplant patients, and it is currently considered as the third largest cause of death in renal transplant patients. ${ }^{[7]}$ The risk of developing cancer after renal transplantation appears to be at least three times higher in transplant patients than in dialysis patients. ${ }^{[8]}$

In our study, the average time between renal transplantation and tumor development was $\mathbf{5 0}$ months. In the study by $\mathrm{Li}$ et $\mathrm{al},{ }^{[5]}$ the duration between renal transplantation and tumor development was found to be 56 months.

The rate of cancer development after renal transplantation is between $4 \%$ and $18 \%$. In the Republic of China, this rate has been reported as $0.56 \%-4.2 \% .{ }^{[9]}$

In the study by Elserwy et al., ${ }^{[10]}$ patients with renal transplantation were investigated with regard to malignancy development in 36 years. The incidence of malignancy was found to be $4 \%$, and the average time of development was found to be 35 months.

In the study by Zilinska et al., ${ }^{\left[{ }^{\prime \prime}\right]}$ in 142 I patients who underwent renal transplantation, the rate of malignity development was $6 \%$, and the average time of malignity development was 45 months.

In the present study, we found that the overall prevalence of post-transplantation malignancy was $2.5 \%$. The rate in our center is lower than that in other centers ${ }^{[10,11]}$ and was in line with the studies of the People's Republic of China. ${ }^{[2]}$

The risk of developing malignancy after renal transplantation is due to exposure to immunosuppressive drugs in higher doses and longer periods due to acute or chronic rejection, exposure to viruses known to be carcinogenic, and the presence of direct carcinogenic immunosuppressive genes. ${ }^{[13]}$

The incidence of hepatic carcinoma after kidney transplant may be associated with higher incidence of hepatitis B. There was one case of hepatic carcinoma in our center, and it was related with hepatitis $B$.

Each transplant center varies obviously with regard to the predilection sites and types of post-operative malignancy of renal transplantation. The most common malignancies in solid organ transplantation are skin and lip carcinoma, followed by lymphoma, Kaposi's sarcoma, cervical carcinoma, renal carcinoma, vulva and perineal carcinoma, hepatic carcinoma, and other malignancies. ${ }^{[14]}$ Similar types of cancer were detected in our study, consistent with previous studies.

Renal carcinoma is more common in patients with acquired kidney cysts. ${ }^{[15]}$ The patient who developed renal carcinoma in the post-transplantation period was neither polycystic kidney disease nor suspicious cyst and mass in pretransplant examination.

Increased dosing of immunosuppressive drugs can lead to the risk of developing cancer. Therefore, the dosage of immunosuppressive drugs should be as low as possible so that patients do not experience rejection, but it is hard to achieve balance between rejection and toxicity. ${ }^{[12]}$

In this single-center study, the number of patients was insufficient to make clear statements. However, similar with other studies, cancer incidence and cancer types were encountered. ${ }^{[5,9-12]}$

In our cancer-developing patients, immunosuppressive drugs were carefully reduced after the cancer operation. We observed no deaths caused by malignity.

Every patient with renal transplantation should be followed up carefully by regular physical examination, laboratory findings, and imaging studies due to the risk of malignancy. Regular imaging of the native kidney, not only the transplant kidney, should be neglected for renal carcinoma. Early diagnosis of malignancy is essential to preserve the benefits of transplantation in both patient survival and functional renal graft.

Ethics Committee Approval

Retrospective study.

Informed Consent

Retrospective study.

Peer-review

Internally peer-reviewed.

Authorship Contributions

Concept: E.P.; Design: E.P.; Data collection \&/or processing: E.P., M.M., S.F.Y.; Analysis and/or interpretation: E.P., A.B.H.; Literature search: E.P., O.A.; Writing: E.P.; Critical review: E.P., Z.B.B.

Conflict of Interest

None declared.

\section{REFERENCES}

1. Suthanthiran M, Strom TB. Renal transplantation. N Engl J Med 1994;331:365-76. [CrossRef]

2. Birkeland SA, Storm HH, Lamm LU, Barlow L, Blohme I, Forsberg, et al. Cancer risk after renal transplantation in the Nordic countries, 1964-1986. Int J Cancer 1995;60:183-9. [CrossRef]

3. Vajdic CM, McDonald SP, McCredie MR, van Leeuwen MT, Stewart JH, Law M, et al. Cancer incidence before and after kidney trans- 
plantation. JAMA 2006;296:2823-31. [CrossRef]

4. Buell JF, Gross TG, Woodle ES. Malignancy after transplantation. Transplantation 2005;80:S254-64. [CrossRef]

5. Li WH, Chen YJ, Tseng WC, Lin MW, Chen TJ, Chu SY, et al. Malignancies after renal transplantation in Taiwan: a nationwide population-based study. Nephrol Dial Transplant 2012;27:833-9.

6. Chiang YJ, Wang HH, Liu KL, Chu SH, Lee WC. Hepatocellular carcinoma following renal transplantation: experience in northern Taiwan. Transplant Proc 2008;40:2397-9. [CrossRef]

7. Wong G, Chapman JR. Cancers after renal transplantation. Transplant Rev 2008;22:141-4. [CrossRef]

8. Berardinelli L, Messa PG, Pozzoli E, Beretta C, Montagnino G. Malignancies in 2753 kidney recipients transplanted during a 39-year experience. Transplant Proc 2009;41:1231-2. [CrossRef]

9. Peng MJ, Yang ZH, Fang ZL. Summary analysis of public reports of kidney transplant malignancy cases. Chinese Journal of Organ Transplantation 2005;26:269-71.

10. Elserwy NA, Lotfy EE, Foudo MA, Mahmoud MI, Donia AF,
Mashaly ME, et al. Postrenal transplant malignancy;incidence risk factors and prognosis. Saudi J Kidney Dis Transpl 2017;28:579-88.

11. Zilinska Z, Sersenova M, Chrastina M, Breza J SR, Bena L, Baltesova $\mathrm{T}$, et al. Occurence of malignancies after kidney transplantation in adults: Slovak multicenter experience. Neoplasma 2017;64:311-7.

12. Wu B, Wang K, Mo CB, Shen ZY. De novo malignancies in renal transplant recipients: experience at a single center in China. Int J Clin Exp Med 2015;8:2911-6.

13. Webster AC, Craig JC, Simpson JM, Jones MP, Chapman JR. Identifying high groups and quantifying absolute risk of carcinoma after kidney transplantation: a cohort study recipients. AM J Transplant 2007;7:2140-51. [CrossRef]

14. Villeneuve PJ, Schaubel DE, Fenton SS, Shepherd FA, Jiang Y, Mao Y. Cancer incidence among Canadian kidney transplant recipients. Am J Transplant 2007;7:941-8. [CrossRef]

15. Schwardz A, Vatandaslar S, Merkel S, Haller H. Renal cell carcinoma in transplant recipients with acquired cystic kidney disease. Clin J Am Soc Nephrol 2007;2:750-6. [CrossRef]

\section{Böbrek Nakli Alıcılarında Malignite}

Amaç: Transplantasyon sonrası gelişen malignitelerin tipi coğrafi ve etnik popülasyonlar arasında farlılıklar göstermektedir. Çalışmamızda böbrek nakli alıcılarında malignite gelişimi riski ve sıklığını, klinik özellikleri ve sonuçlarını değerlendirmeyi amaçladık.

Gereç ve Yöntem: Merkezimizde Ocak 2005 ile Aralık 2016 arasında takip edilen 322 böbrek nakli alıcısı değerlendirmeye alındı. Nakil tarihi, demografik veriler, kanser tanısıla ilgili veriler kayıt edildi.

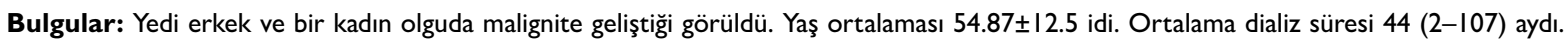
Nakilden malignite tanısına kadar geçen süre 50 (dağılım, 7-93) aydı. Tün böbrek nakli alıcıları arasında malignite gelişme oranı \%2.5 olarak hesaplandı.

Sonuç: Transplantasyn uygulanan olguların malignite yönünden fizik muayene, laboratuvar değerlendirmesi ve görüntüleme yöntemleri ile yakın takibi gerekir. Erken tanı, hastanın ve nakil böbreğin sağkalımı için hayati değerdedir.

Anahtar Sözcükler: Böbrek nakli; kanser; malignite. 